\title{
Farmer Evaluations Of The System Of Rice Intensification (SRI) Compared With Conventional Rice Production In Benin
}

\author{
Pascal Gbenou \\ Université d’Agriculture de Ketou (UAK), Adjohoun, Benin, West Africa \\ Laboratoire de Recherche en Ecologie Animale et de Zoogéographique \\ (LaREZ), Ketou \\ Anne-Marie Mitchel \\ Cornell University, USA \\ Adjahossou B. Sedami \\ Ecole Polytechnique d'Abomey Calavi (EPAC) \\ Pr. Noukpo Agossou \\ Université d'Abomey Calavi
}

doi: 10.19044/esj.2016.v12n30p280 URL:http://dx.doi.org/10.19044/esj.2016.v12n30p280

\begin{abstract}
This article summarizes the evaluation of a new method for rice cultivation, the System of Rice Intensification (SRI), by a group of 90 rice farmers in Benin. Between August 2009 and June 2012, a series of tests were conducted in two rice ecosystems on 32 plots. This farmer-conducted research focused on the new methodology's agronomic performance and its labor and seed requirements, also considering what would be the constraints on adoption. The trials showed that SRI methods could increase average yields under farmer conditions by $54 \%$, while reducing seed requirements by $87 \%$ and shortening the growing season by 14 days. To achieve these benefits required an increase in the amount of labor, by $36 \%$. Producers participating in this evaluation concluded that SRI offers significant opportunities to increase their rice production, provided its methods are adapted to local conditions
\end{abstract}

Keywords: System of Rice Intensification (SRI), farmer evaluation, Benin

\section{Executive Summary}

The System of Rice Intensification (SRI), reported by some researchers and practitioners to give very high performance, is still controversial in some scientific circles because the reported increases in 
yield are achieved with reductions in material inputs. This is an inversion of usual agriculture technology, where more inputs are required to achieve even greater increases in output. Producing more output with less input makes nonsense of standard benefit-cost ratio (BCR) analysis, for example. Achieving production increases by mobilizing biological processes and potentials that can magnify input effects represents a different paradigm for agricultural R\&D from the Green Revolution which depended on increases in agrochemicals and water with new varieties bred to be particular responsive to such increases.

SRI methods were evaluated by 90 rice farmers in Benin from 2009 to 2012, with two years of formal replicated on-farm trials. This article summarizes farmers' experience with this new rice cultivation methodology in comparison with their usual practices under their own field conditions. The research design, developed with and by the farmers, tested use of SRI methods in two different ecosystems for growing rice (upland plateau and lowland floodplain). It monitored and measured results from 32 plots from which controlled comparisons could be made regarding key parameters such as crop yield and labor requirements.

The results revealed significant agronomic and economic differences between the productivity of SRI and farmers' present methods. SRI increased the amount of farmers' work on average by $32 \%$ in comparison to both conventional management practices and a farmer-adapted system (Table 4). However, farmers achieved considerably higher yields which more than compensated for this increased labor. Since current African rice production is usually relatively labor-extensive, not intensive as in most of Asia, there is corresponding low yield, and practically any improvement in rice production will require some increase in labor.

Average yields with SRI ranged from 8,806 kg per hectare on the floodplain to $8,687 \mathrm{~kg}$ per hectare on the plateau. This represented an increase of about $50 \%$ over farmers' conventional practices, whose yield averaged 5,813 kg (Figure 4). That the SRI crop performance was quite similar in the two contrasting agroecosystems was itself an interesting finding from farmers' evaluation. They found that SRI practices reduced their seed requirements by $87 \%$ and shortened the crop's growing cycle on average by 14 days, which favorably impressed the participating rice farmers.

Rice producers when interviewed about problems or limitations with the new methods reported constraints regarding water control (need to control water intake and especially to maintain drainage in the lowlands), access to biomass materials for making compost, and lack of financial resources as factors that can inhibit their adoption of SRI. Farmers concluded that SRI offers a good menu of technical options for increasing their 
production of rice, and that it is both flexible and adaptable to local conditions.

\section{Introduction}

Rice, the staple food for about half of the world's population, is produced almost everywhere in the world, although mostly concentrated in Asia, with about $90 \%$ of production. Only $7 \%$ of the volume of rice produced by farmers around the world is traded internationally (FAO, 2011). Faced with very strong pressures on its land and water resources, Asia will become less and less able to supply the world's rice market, foreboding serious global consequences for food and nutrition, particularly in countries where rice production is not yet at a very technically-advanced level (Mendez del Villar et al., 2013). Countries dependent on rice imports like those in West Africa need to have their own means to bridge the gaps between their rice consumption and production to avoid far-reaching and complex crises (AfricaRice, 2011; Galtier, 2012).

Like most West African rice-producing countries, Benin's national production covers only $60 \%$ of its current national rice consumption needs, necessitating large and growing imports. This demand can be expected to increase as population grows due to future births and immigration. Multiple assessments - by Verlinden and Soulé (2003), Adegbola Sodjinou (2003), Capo-Chichi (2004), and more recently AfricaRice (2011) and Seck et al. (2013) - have pointed to the serious problem created by farmers' low rice yields, which in Benin are currently less than 3 tons per hectare.

Current technologies and practices are evidently not sufficient to meet national needs, and expanding the area devoted to rice would come at the expense of other food production (Chouquer, 2011; VECO, 2012). To feed its growing population, more intensive methods of rice production, more efficient use of inputs, and more resilience in the face of climate change are essential, not just in Benin but also elsewhere in the region (Agrisud, 2010; Ahmadi et al., 2013).

Benin rice producers, looking for alternative methods of production that can significantly increase rice supply without jeopardizing the health and sustainability of ecosystems, have been attracted to the agronomic performance reported for SRI, e.g., Uphoff (2003), Balasubramanian et al. (2007), Sinha and Talati (2007). However, SRI performance has been the subject of some academic controversy, e.g., McDonald et al. (2006). Despite this, it is becoming clear that SRI is an attractive strategy for introducing and improving best management practices and for empowering smallholder farmers. At least it deserves objective evaluation.

After witnessing some initial trials using SRI methods, dozens of Benin rice farmers decided in 2008 to undertake their own assessment of 
these practices by making systematic comparisons of yield and other parameters such as the length of the crop cycle and the work required, comparing their usual methods with SRI (Gbenou, 2009). This paper presents results from farmer trials in two communes (Adjohoun and Bonou) located in different parts of the Ouémé Valley (Figure 1). This region is located in the Department of Ouémé in southern Benin. The data collected over three years include the quantity of seed used/required, the duration of the crop production cycle, resulting grain yields, and working time involved.

\section{Methods and Materials}

The results from an initial comparison of SRI versus conventional methods in trials conducted in 2008 motivated the planning and implementation of a more formal and structured study with in-situ tests conducted in two ecological zones by rice farmers under the auspices of the Consultation Council of Rice Producers in Benin (CCR-B). Its members wanted to assess the relative merits of SRI, farmer-adaptations, and conventional methods. The results of this evaluation, done over a three-year period, are reported here.

\subsection{Experimental materials}

For all of the trials, the rice variety used was IR-841, an improved variety that has taste and other qualities highly appreciated by consumers in Benin. The soils in which the trials were conducted were whatever soils the participating farmers had available for cultivation. The soils were thus not standardized but represented the variety and range of soils in the respective study areas. While this research design did not have as much precision as onstation trials, it had the compensating advantage of realism in that the materials used for growing rice represented those that are used under Benin farmers' actual conditions of cultivation.

Trials were conducted over three years (2009/10, 2010/11 and 2011/12) concurrently in two different environments for growing rice, both on the plateau (at Kakanitchoé) and in the floodplain (at Dogba). This permitted assessments of SRI effects in the two main ecosystems for rice cultivation in the region. After the field trials, participating farmers were asked questions concerning their perceptions of the advantages or disadvantages of SRI; about associated constraints, adoptable and adaptable techniques; and what is necessary to increase the utilization of said techniques.

A total of 90 rice farmers from all the major rice-growing areas of Benin -- the Niger Valley, Ouémé, Couffo, Koussin-lélé, Boukoumbé, Tanguiéta, Dassa, Savè -- participated in the planning and conduct of the trials. Of these, 54 were farmers who worked directly on the trial plots in the 
region of study; the remaining 36 were rice farmers who do not live in the test areas but who came from their homes to the field on five different occasions (different phases of the cropping cycle) to engage in (a) preparing the soil, (b) establishing the nursery, (c) transplanting seedlings, (d) observing flowering, and (e) harvesting the trial plots.

Generally speaking, crop management was not done as intensively as is common in most Asian countries, or in some other parts of Africa, either for the SRI or for the conventional rice plots. But as noted, these trials were conducted under the most realistic circumstances, with farmers involved in the planning as well as in the execution of the trials through the CCR-B. Most communes in Benin where rice is grown have a local association of rice farmers that functions as a member unit of CCR-B, and the farmers who participated in this study were all representatives of this Council.

It was decided by the farmers themselves to conduct this evaluation collaboratively, with plots set up in the two respective locations, to represent the major ecosystems for rice production in Benin. As noted above, most of the rice farmers who participated directly in the study were from one of these two areas. However, farmers from other communes associated with CCR-B agreed to participate in the work and the evaluation, so that whatever was learned from the trials could inform other rice farmers all over the country. The planning and conduct of this evaluation, both for farmers and by farmers, was thus rather original.

The participating farmers also decided to assess their own 'farmeradapted' methodologies in these trials, which would be somewhat different from both the SRI and conventional methods and would represent an amalgamation of the two. Participants wanted to generate more information from this study that would enable Beninese rice farmers to better decide for themselves what management practices they would like to adopt or adapt, based on what they had witnessed.

This concept of evaluating farmer-chosen practices 'between' SRI and current farmer practices, to have three sets of data for comparison is similar to the farmer-participatory program set up under an EU-funded program based at the Asian Institute of Technology for introducing and evaluating SRI method in Cambodia, Laos, Thailand and Vietnam, countries in the Lower Mekong River basin. That program supported farmers to compare results of using their current practices, SRI, and some combination of the two (Mishra et al., 2016).

Figure 1 shows where the testing occurred in relation to the communes from which the 54 Ouémé Valley rice farmers cultivated the trial plots together. These farmers were divided into two groups based on their proximity to the respective trial locations -- Dogba in the floodplain, and Kakanitchoe in the plateau area. 


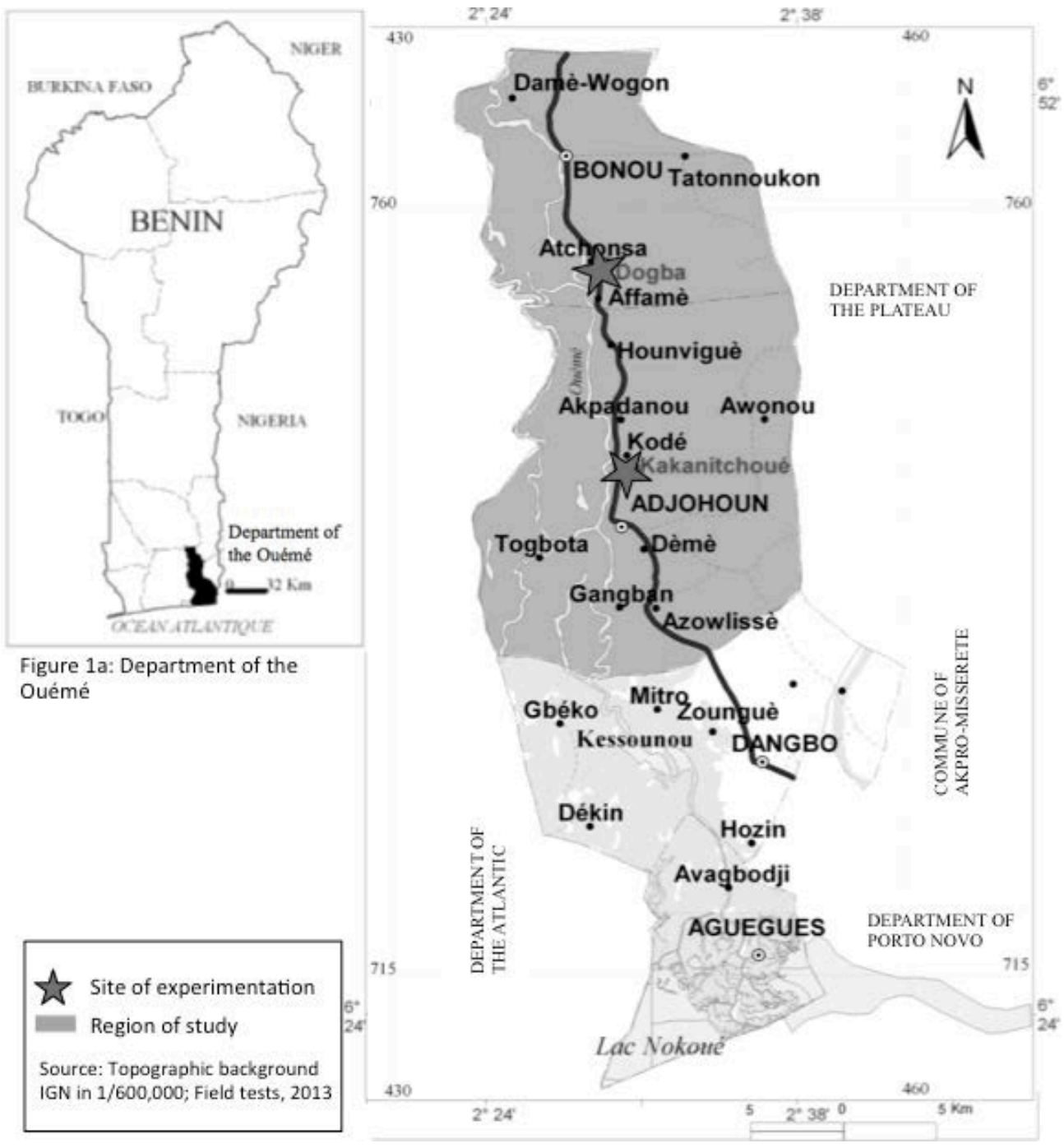

Figure 1: Locations of the two test sites, Dogba and Kakanitchoe, located along the Ouémé River running north-south through the Department of Ouémé, shown in black in the inset map of Benin (Figure 1).

The other 36 participating farmers who reside away from the trial areas were selected from Benin's other main rice-producing areas to ensure a good range and distribution of rice interests and knowledge. This could contribute to the most appropriate testing and evaluation of SRI methods within the larger national context. The municipalities and the villages where these farmers were located and came from are shown in Figure 2. 


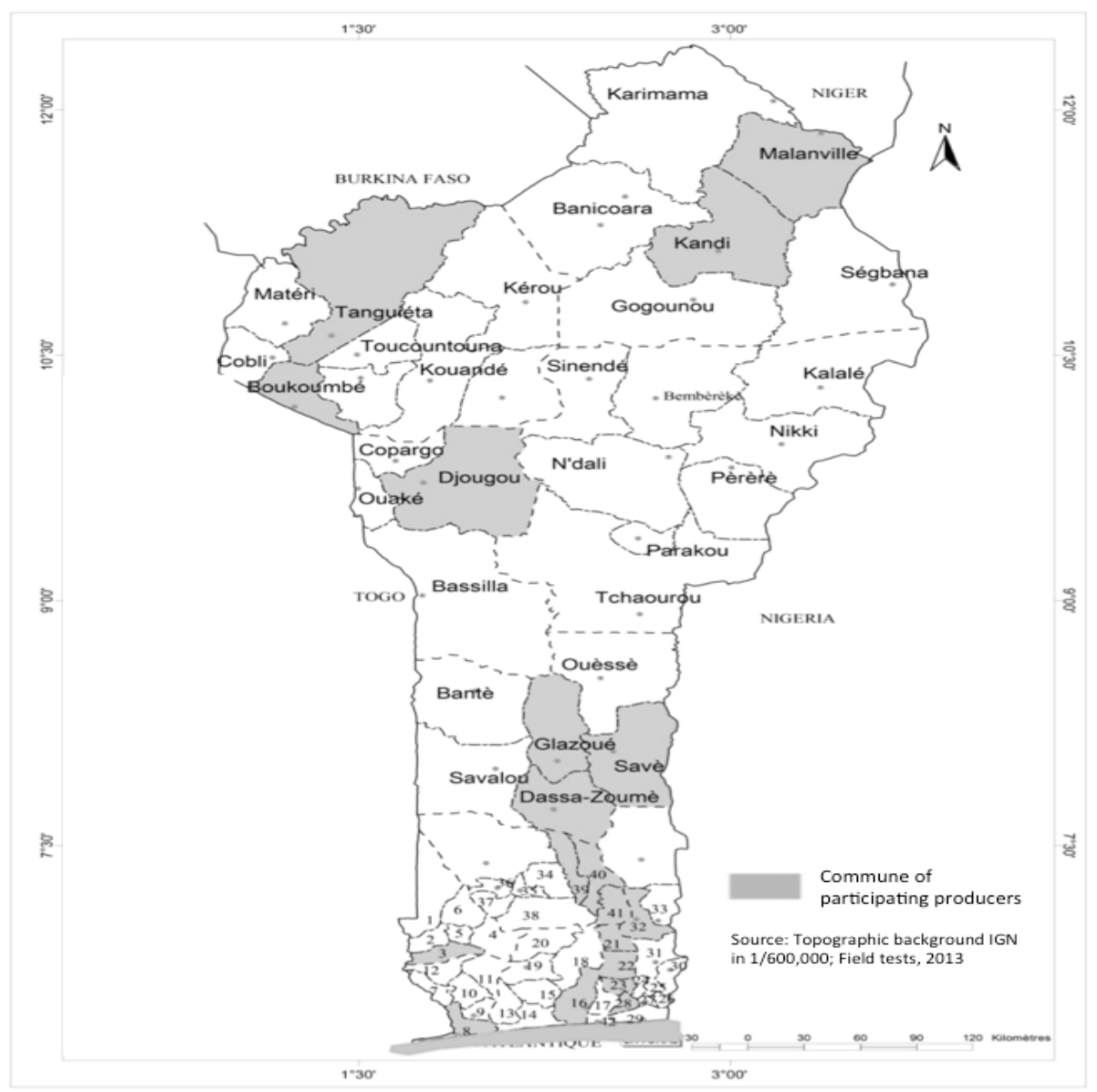

Figure 2: Communes where other participating rice producers resided

\subsection{Experimental methods}

Each site contained eight plots with two replications of the four treatments under evaluation, as shown in Table 1. The design for testing alternated the layout of plots to ensure that plots with the same combination of factor values were not repeated in the same location.

- $\quad$ Three production systems were evaluated: (1) SRI, on plots cultivated according to the principles of SRI; (2) a farmer adaptation, on plots where farmers followed most of their usual methods but transplanted seedlings just 8 days old, to see what the effect of early transplanting would be; and (3) conventional practice, on plots cultivated according to farmers' standard methods, using seedlings that were 30 days old.

- Two ecologies were evaluated: upland plateau, and lowland floodplain. Rice fields in the floodplains have their fertility renewed each year when flooding by the Ouémé River leaves rich deposits of silt. Fields on the plateau, on the other hand, which do not have this natural soil 
enrichment, often have fertilizer applied. For these trials, compost was brought up from the floodplain and applied at a rate of 12.5 tons per hectare. The decision to bring compost to the plateau test sites was made by the producers themselves in order to have similar soil fertility conditions for both sets of trials.

SRI plots were transplanted with single seedlings, either 8 or 12 days, with one seedling per hole and 25 x $25 \mathrm{~cm}$ spacing. In the conventional plots, seedlings were transplanted at 30 days with 3-5 seedlings per hole, and with no specified care given to spacing. The farmer-adapted method tested transplanting 8-day-old seedlings 3-5 per hole, and with no specified care given to spacing.

The design of the trials, with two replications of each of the four treatments being evaluated, was replicated at the two different sites. This design was repeated in the second year, so that there was replication also over time. Table 1 describes the respective treatments evaluated in the first and second seasons at the Dogba, and Kakanitchoé sites.

Table 1: Test factors for each experimental field.

\begin{tabular}{|c|c|c|c|c|}
\hline Site & $\begin{array}{l}\text { No. of } \\
\text { plots }\end{array}$ & $\begin{array}{c}\text { Plot } \\
\text { paramet } \\
\text { ers }\end{array}$ & Ecosystem & Type of experiment \\
\hline $\begin{array}{c}\text { Dogba: } \\
\text { Year } 1 \\
(2009 / 10) \\
\end{array}$ & 08 & $\begin{array}{c}625 \mathrm{~m}^{2} \mathrm{x} \\
8 \text { plots }\end{array}$ & $\begin{array}{c}\text { Floodplain, } \\
\text { without } \\
\text { compost } \\
\end{array}$ & $\begin{array}{c}2 \text { plots SRI @ } 8 \text { days; } 2 \text { plots SRI } \\
\text { @ } 12 \text { days }\end{array}$ \\
\hline $\begin{array}{l}\text { Kakanitch } \\
\text { oe: } \\
\text { Year } 1 \\
(2010 / 11) \\
\text { and Year } 2 \\
(2011 / 12) \\
\end{array}$ & 08 & $\begin{array}{l}400 \mathrm{~m}^{2} \mathrm{x} \\
8 \text { plots }\end{array}$ & $\begin{array}{c}\text { Plateau, } \\
\text { with } \\
\text { compost } \\
\text { added to the } \\
\text { soil }\end{array}$ & $\begin{array}{l}2 \text { plots SRI @ } 8 \text { days; } 2 \text { plots SRI } \\
\text { @ } 12 \text { days } \\
2 \text { plots conventional; and } 2 \text { plots } \\
\text { with farmer- adaptation (young } \\
\text { seedlings) }\end{array}$ \\
\hline
\end{tabular}

Note that the experiments in Kakanitchoé and Dogba were not conducted all at the same time, as the two sets of trials occurred over a threeyear time frame, with trials overlapping in the middle year (2010/11). Of the eight plots established at each site each year, two were managed with conventional rice cropping; two with the farmer-adapted system; and the remaining four were used to evaluate SRI methods: two plots with rice seedlings transplanted at 8 days, and two plots with seedlings transplanted at 12 days.

\section{Results and Discussion}

\subsection{Comparisons of agronomic performance of the different systems}

The parameters evaluated at the selected sites included the average number of tillers per hill, the ratio of number of plants to yield (to assess the economical use of seed), and the duration of the crop cycle from planting to 
yield. These findings showed significant yield improvements associated with SRI, despite ecological differences.

\section{$>\quad$ Tillers per hill and average number of plants}

Differences between the cropping systems were evident already at the tillering stage. SRI-grown plants developed a greater number of tillers than those grown with conventional production practices. This result was also evident with the farmer-adaptive trials, which used younger seedlings than farmer usually transplant. Thus the young-seedling effect was clearly demonstrated for all the farmers to see.

The average number of tillers per hill with SRI methods was 46 (from a single plant), while with conventional practices the number of tillers per hill (with 3-5 plants) was 19, about one-tenth as many tillers per plant. The farmer-adaptation hills were intermediate with 26 tillers (for 3-5 plants transplanted at 8 days). This was about one-seventh as many tillers per plant as with SRI methodology.

Farmers were impressed that although SRI used about 7 times fewer plants on an area basis than their own usual practices, when harvesting, the number of panicles per $\mathrm{m}^{2}$ was higher on SRI plots. Planting single seedlings with SRI practices produced 50\% more tillers per unit area than the conventional system practice, which had 3-5 seedlings per hill.

These results are consistent with the work of Laulanié (1993), Stoop et al., (2002), and Serpantié et al. (2013), showing that the technical methods of SRI avoid the growth-limiting factors introduced by transplanting stress when older seedlings are used and when transplanting is done quickly and carefully. SRI practice seeks to minimize desiccation and trauma for the roots. Also, it minimizes the inhibition of growth for tillers (and roots) that comes from denser planting. Table 2 summarizes the data for the transplanting and tillering.

Table 2: Average number of tillers per hill, number of plants, and yield, averaged over the two years at each site (numbers in parentheses represent one standard deviation).

\begin{tabular}{|c|c|c|c|c|c|}
\hline \multirow{2}{*}{ Agroecosystem } & Methods & $\begin{array}{c}\text { Average no. of } \\
\text { tillers per hill }\end{array}$ & $\begin{array}{c}\text { Number of } \\
\text { hills per } \\
\text { hectare }\end{array}$ & $\begin{array}{c}\text { No. of } \\
\text { tillers } \\
\text { per }{ }^{2}\end{array}$ & Yield \\
\hline \multirow{3}{*}{ Floodplain } & SRI & $54.0( \pm 2.6)$ & 160,000 & 864 & $8,806( \pm 523.9)$ \\
\cline { 2 - 6 } & Conventional & $19.5( \pm 1.3)$ & 333,333 & 650 & $5,816( \pm 95.6)$ \\
\cline { 2 - 6 } & Farmer-adapted & $32.0( \pm 1.8)$ & 333,333 & 1,067 & $7,028( \pm 35.5)$ \\
\hline \multirow{3}{*}{ Plateau } & SRI & $41.9( \pm 12.3)$ & 160,000 & 670 & $7,680( \pm 14.0)$ \\
\cline { 2 - 6 } & Conventional & $19.9( \pm 4.8)$ & 333,333 & 663 & $5,121( \pm 185.7)$ \\
\cline { 2 - 6 } & Farmer-adapted & $22.5( \pm 4.4)$ & 333,333 & 746 & $6,054( \pm 826.8)$ \\
\hline & SRI & $\mathbf{4 8 . 0}$ & $\mathbf{1 6 0 , 0 0 0}$ & $\mathbf{7 7 2}$ & $\mathbf{8 , 2 4 3}$ \\
\cline { 2 - 6 } & Conventional & $\mathbf{1 9 . 7}$ & $\mathbf{3 3 3 , 3 3 3}$ & $\mathbf{6 5 6}$ & $\mathbf{5 , 4 6 8}$ \\
\cline { 2 - 6 } & Farmer-Adapted & $\mathbf{2 7 . 3}$ & $\mathbf{3 3 3 , 3 3 3}$ & $\mathbf{9 0 6}$ & $\mathbf{6 , 5 4 1}$ \\
\hline
\end{tabular}

Source: Analysis of data from trials in 2009/10, 2010/11 and 2011/12 


\subsection{Crop cycle duration}

Regarding the length of the crop cycle, SRI practices were seen to promote a shortening of the crop cycle by about 14 days, while giving higher yield. So that the increase in field productivity on a per-day basis was even greater than reflected in yield differentials. This also was of considerable interest to the participating farmers.

Shortening the crop cycle for rice with the SRI method is mainly due to the earlier transplanting, but it also reflects acceleration in the plant's metabolism and growth as the methods promote healthy root development. Shortening of the crop cycle can reduce the risks related to hydro-climatic hazards, especially toward the end of the season. It can also diminish the crop's exposure to pests and diseases. This result is consistent with reports of Styger (2009) in Mali and of Uphoff (2007) in Madagascar, where shortening of the crop cycle with SRI management was also reported.

Figure 3 shows substantial differences in the average duration of the crop cycle among the SRI, farmer-adapted, and conventional systems.

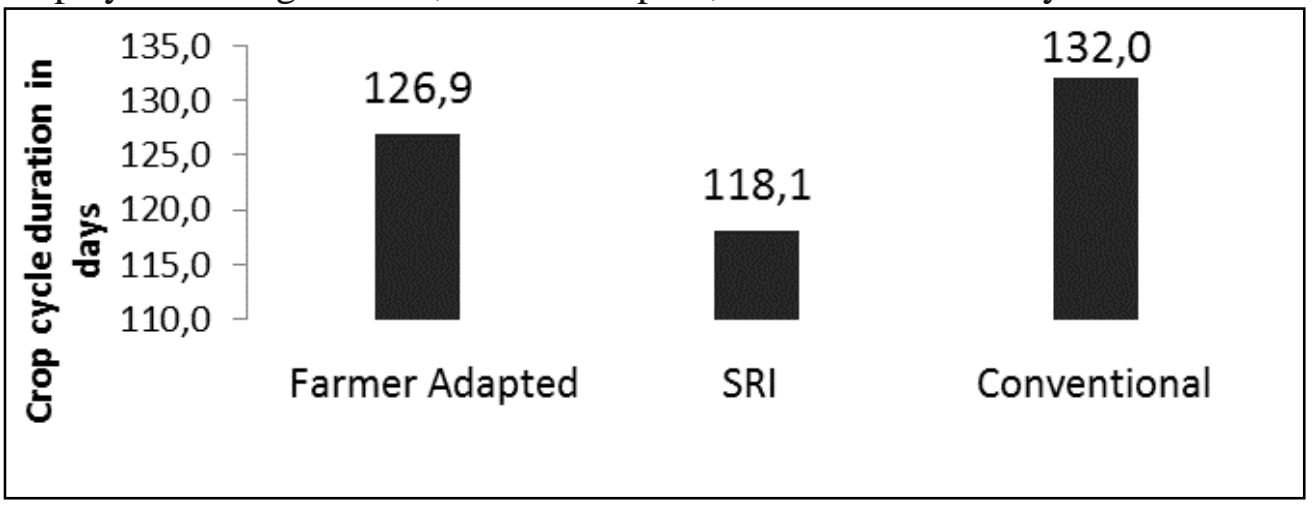

Figure 3. Crop cycle duration of rice by system

Source: Field tests, 2009/10, 2010/11, and 2011/12

\subsection{Differences in yield}

Figure 4 shows the significant differences in yield among the three different management methods in the two different ecosystem environments. The first finding was that the pattern of yield differentials is the same between the two environments, with floodplain yields averaging $2.3 \%$ higher across the four sets of trials, but with the differences fairly uniform across the cultivation methods. Yields within the two ecosystems (floodplain and plateau) with the three production systems (SRI, conventional, and farmeradapted) varied between 5,809 $\mathrm{kg}$ and 9,256 $\mathrm{kg}$ per hectare, the high end $60 \%$ more than the low end of the range. 


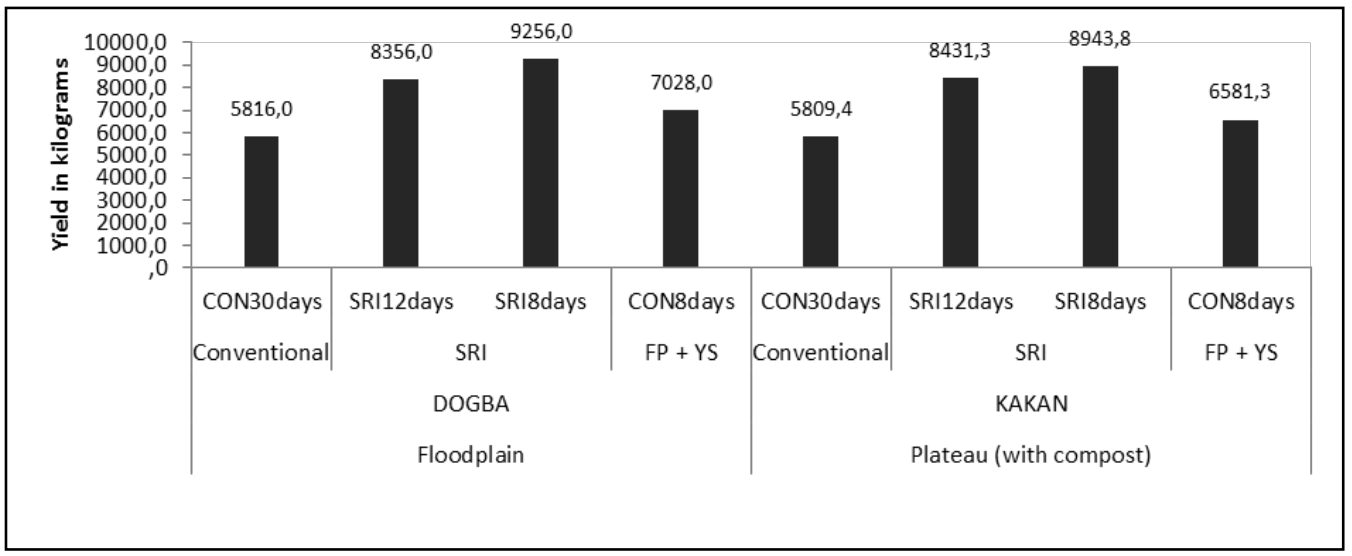

Figure 4: Comparison of rice grain yields in plateau and floodplain production systems. (Key: CON 30days $=$ Conventionally grown, transplanted at 30 days) Source: Field tests, 2012

The best results were obtained on the SRI plots, being 44\% higher with 12-day seedlings and 56\% higher with 8-day seedlings compared with conventional methods, while the plots with farmer-adapted methods (8-day seedlings and conventional practice) yielded $17 \%$ more than current farmer methods. Use of younger seedlings transplanted at 8 days with SRI management methods added $8 \%$ to yield compared to that achieved with 12 day seedlings transplanted using SRI methods.

These results are consistent with those reported by Uphoff (2004, 2005, 2007, 2009). When considering the agronomic, environmental, and economic aspects of rice production, Uphoff concludes that SRI management achieves greater production using fewer resources, particularly land and water, which are becoming increasingly limited and limiting.

Results in Kenya reported by Mati et al. (2009, 2011) have shown similar comparative advantages arising from SRI practice, including higher yields ranging from $84-100 \%$ increase, lower production costs, better grain quality, and conservation of irrigation water. In Mali, SRI methods have increased paddy yields by more than $66 \%$ in comparison to the best yields from traditional farmers' practices (Styger 2009). The yield gains reported from Madagascar by Serpantié et al. (2013) are more modest, in the range of $5 \%$ to $16 \%$.

SRI results vary widely at least in part because one of the main contributing factors is the effects of beneficial soil organisms (Anas et al., 2011), whose abundance, diversity and activity can vary considerably in response to differences in crop management, climatic influences (rainfall and temperature), and soil characteristics $(\mathrm{pH}$, composition, aggregation, porosity, etc.). Also, the skill with which SRI methods are used can have an effect on rice plants' growth and performance. All these factors mean that variability in results is to be expected. That the results obtained from two 
years of trials in quite different agroecosystems were so similar gave farmers more confidence in what they observed.

\subsubsection{Economic performance}

This was affected by the quantities of seed used, by the influences of the climate and ecosystem, and by the amount of labor required on the test fields, including for provision and transport of compost. There were very little differences in land or water inputs because the rice plots were given the same quantity of water and fertilization as part of the comparative evaluation. The plots primarily relied on and received water through rainfall and residual moisture. When it did not rain, the plots were watered three times per week using a motorized pump. The plots were watered just until the ground was moist, with no standing water, and the overall quantity of water given to each plot was estimated.

\subsubsection{Use of seed}

Table 3 shows the quantities of seed used with the different cultivation systems. The data show that the practice of SRI reduced seed requirements by $87 \%$ compared to conventional cultivation. This level of SRI seed saving for producers at the beginning of the sowing season resulted in savings of about 49,500 CFA francs (approximately \$100 USD) per hectare that otherwise had to be spent for the purchase of seed.

This expenditure must be made at a time when farmer's cash reserves are lower than usual, so this reduction is of benefit to households over and above the amount of money that is involved. Instead of having to buy $53 \mathrm{~kg}$ of seed at 1,000 CFA francs per kg, only $7 \mathrm{~kg}$ were necessary, saving about $\$ 78$ USD per hectare. This effect is very close to that reported from Mali where the rate of seed saving with SRI was 90\% (Styger et al.., 2009). In the evaluation of SRI in Madagascar by Serpantié et al. (2013), the economy of seed saving was the only indisputable advantage of SRI.

Table 3: Seed quantities used per hectare for the different systems (the numbers in parentheses represent one standard deviation)

\begin{tabular}{|c|c|c|}
\hline \multicolumn{2}{|c|}{ Agroecosystem Method } & Average amount of seeds used in kg \\
\hline \multirow{3}{*}{ Floodplain } & Conventional & $53.8( \pm 0.0)$ \\
\cline { 2 - 3 } & SRI & $6.7( \pm 0.0)$ \\
\cline { 2 - 3 } & Farmer-adapted & $51.5( \pm 0.0)$ \\
\hline \multirow{3}{*}{ Plateau } & Conventional & $56.6( \pm 1.0)$ \\
\cline { 2 - 3 } & SRI & $7.0( \pm 0.1)$ \\
\cline { 2 - 3 } Average & Farmer-adapted & $52.0( \pm 0.8)$ \\
\hline & SRI & $\mathbf{6 . 8 5}$ \\
\cline { 2 - 3 } & Conventional & $\mathbf{5 5 . 2}$ \\
\cline { 2 - 3 } & Farmer-adapted & $\mathbf{5 1 . 7 5}$ \\
\hline
\end{tabular}

Source: Field trials, 2012 


\subsubsection{Requirements for labor}

The amount of labor involve for SRI practice seem to be the main limiting factor for expansion of the system. The results of our evaluation indicated that this system required about 38\% more labor per hectare, at least initially. This increased requirement is unevenly distributed among the different cropping operations. For example, good leveling of the field required $77 \%$ more time, while transplanting required $70 \%$ more. Weeding SRI plots required, on the other hand, $47 \%$ less labor time compared to the conventional system.

These data are fairly consistent with those reported from Madagascar by Moser and Barrett (2003). Those authors reported: "SRI demands between 38 and 54\% more work compared to the traditional technique, 62\% of the additional work being dedicated to weeding, and $17 \%$ to transplanting." The big difference with Moser and Barrett's work in Madagascar is that weeding of SRI plots in Benin required less labor rather than more.

The data reported here are from first or second-year use of SRI methods, and a number of studies have shown that the labor time needed for SRI cultivation is reduced as farmers gain skill and experience with the methods. An evaluation of SRI experience in Cambodia by Anthofer (2004), sponsored by GTZ and covering 500 randomly-sampled farmers in 5 districts, found that over time SRI required less labor than conventional methods and accordingly became more profitable. While more-experienced producers reduced their labor per hectare by $8 \%$ compared to conventional practices, new SRI farmers practicing its transplanting methods for the first time needed between 10 and $20 \%$ more time for this work while the methods were being learned. The conclusion by Moser and Barrett (2003) that SRI requires more labor per hectare was amended when they, with two other colleagues who had done more extensive field studies in Madagascar, evaluated SRI labor requirements from a time perspective. They found that by the $4^{\text {th }}$ and $5^{\text {th }}$ years, SRI practice reduced total labor inputs compared to their usual practices by $4 \%$ to $10 \%$ (Barrett et al., 2004).

Rice production in Madagascar and most African countries is traditionally very labor-extensive as population pressure on the land has not been as great as it is in most Asian countries. How labor-intensive SRI practices will be depends as much on the prevailing rice cultivation practices (the standard for comparison) as on SRI requirements themselves. Table 4 shows the average requirements per hectare for the different operations in rice production for the different cropping systems (in days per hectare). 
Table 4: Average workforce (days per hectare) for SRI (using the average for 8-day and 12day seedlings), the farmer-adapted, and conventional systems

\begin{tabular}{|c|c|c|c|c|c|c|}
\hline Ecosystem & \multicolumn{3}{|c|}{ Plateau } & \multicolumn{3}{c|}{ Floodplain } \\
\hline $\begin{array}{c}\text { Operations } \\
\text { Weeding before } \\
\text { planting }\end{array}$ & 17.0 & 17.0 & 17.1 & 22.0 & 25.0 & 25.0 \\
\hline $\begin{array}{c}\text { Conventional } \\
\text { Collection of cut weeds }\end{array}$ & 6.9 & 6.9 & 6.8 & 8.0 & 7.0 & 8.0 \\
\hline adapted & SRI & Conventional & $\begin{array}{c}\text { Farmer- } \\
\text { adapted }\end{array}$ & SRI \\
\hline Uprooting of seedlings & 31.0 & 31.0 & 31.0 & 31.0 & 36.0 & 36.0 \\
\hline Leveling & 32.0 & 8.7 & 13.6 & 7.0 & 7.0 & 7.0 \\
\hline Manure spreading & 8.4 & 7.5 & 8.0 & 0.0 & 0.0 & 0.0 \\
\hline Nursery & 13.3 & 9.9 & 5.6 & 13.0 & 13.0 & 13.3 \\
\hline Transplanting & 20.0 & 54.2 & 93.0 & 22.0 & 56.2 & 99.0 \\
\hline Manual weeding & 118.2 & 106.0 & 62.0 & 111.2 & 106.0 & 55.0 \\
\hline $\begin{array}{c}\text { Harvesting, bundling } \\
\text { and collecting }\end{array}$ & 13.0 & 15.7 & 18.7 & 13.0 & 15.7 & 17.7 \\
\hline Threshing & 19.0 & 21.0 & 26.0 & 20.0 & 21.0 & 32.0 \\
\hline Total & 288.8 & 310.9 & 399.4 & 284.5 & 317.8 & 393.3 \\
\hline
\end{tabular}

Source: Field trials, 2013

The data in Table 4 show that the average SRI plot required 38\% more labor inputs per hectare than for conventional cultivation. Cropping operations that required the most labor were: manual weeding, hoeing, leveling, and transplanting. Deviations were statistically significant in the comparison of means between SRI and conventional systems for the following operations: leveling, transplanting, and weeding.

\subsection{Economic implications}

The increase in yield with SRI management more than compensated for the increased expenditures on labor, detailed in the previous section. On average, when cost of labor (approximately 2000 FCFA per person per day/\$4 USD) is subtracted from the amount gained from the harvest of higher yields (150 FCFA per kilogram/\$0.30 USD), SRI exhibited 42\% higher net earnings than conventional systems, i.e., 221,000 FCFA ( $\$ 442$ USD).

\section{$>\quad$ Farmers' perceptions}

Perception analysis using the Q methodology was used to analyze the results. The use of Q methodology helped to highlight the producers' on various aspects related to SRI. In short, the list of eleven favorable points, eight constraints, three adoptable principles and three suitable principles. Those farm opinions are consistent with the work of Dabat et al. (2007) in Madagascar. 


\section{Conclusion}

Field trials conducted in Kakanitchoé and Dogba by 90 farmers over a three-year period to evaluate alternative methods of rice cultivation produced significant results that have the potential to improve the trajectory for rice production in Benin. The data and analyses reported above, encompassing the geographical differences between floodplains and plateau lands, indicate that applying ideas and methods deriving from the System of Rice Intensification can help to significantly increase the national rice supply, as well as farm household incomes. Being able to earn more than $\$ 400$ USD additional income per hectare from rice production would definitely improve households’ well-being and security

With implementation of SRI, adapted to local conditions, it should be possible to increase rice yields throughout much of Benin without needing to utilize large inputs of chemical fertilizer, or to make significant increases in labor, or to depend on advanced or unattainable technologies. For the health and development of Benin's agriculture and for enhanced rice production in the West African region, this experience and analysis of farmer-based research and evaluation deserve broader consideration.

\section{Acknowledgements:}

Many thanks to Norman Uphoff (Cornell University) for his suggestions and guidance in realizing the publication of this paper.

\section{References:}

1. Adégbola P. and Sodjinou E. (2003) Analyse de la filière de riz au Bénin (Analysis of the rice sector in Benin). Rapport définitif, PADSA-PAPA/INRAB, Porto-Novo, Bénin, 232p.

2. AfricaRice (2011) Tendances rizicoles pour 2011: Rapport annuel. (Rice trends for 2011: Annual report), 101p.

3. Agrisud International (2010) L’agroécologie en pratiques (Agroecology in Practice); Guide Edition 2010, 188p.

4. Ahmadi N. and Bouman B.A.M. (2013) Riz et rizicultures, enjeux économiques, écologiques et scientifiques (Rice and rice farmers issues of economy, ecology, and science). Cahiers Agriculture 22: 333-5.

5. Anthofer J. 2004 : Evaluation of the System of Rice Intensification in Cambodia, February-April. Report to GTZ, Phnom Penh, 99p.

6. Balasubramanian V., Sie M., Hijmmans R.J. and Otsuka K. (2007) Increasing rice production in sub-Saharan Africa: Challenges and opportunities. Advances in Agronomy 94:: 55-133.

7. Barrett C.B., Moser C.M., McHugh O.V. and Barison, J. (2004) Better technology, better plots or better farmers? Identifying changes 
in productivity and risk among Malagasy rice farmers. American Journal of Agricultural Economics, 86: 869-888.

8. Chouquer, G. (2011) L'afrique est t'elle disponible? Ce qu'on voit quand on regarde (Is Africa available to you? What we see when we look). Revue d'Inter reseaux , Grain de sel (57) : 7-8

9. Dabat M., Jenn-Treyer O. et Grandjean P. (2007) Une deuxième chance pour le système de riziculture intensive à Madagascar ? Colloque scientifique, Antanarivo sur le thème: " Dynamiques rurales à Madagascar: perspectives sociales, économiques et démographiques », 28p.

10. FAO (2011) Production et superficie mondiales de riz (Production and Area of Rice in the World). Résumé du suivi du marché du riz, relevé de avril, $5 p$

11. Gbénou P. (2009) Riziculture et souveraineté alimentaire au Bénin: apports des périmètres irrigués (Rice and food sovereignty in Benin: contribution of irrigated areas). Université d'Abomey -Calavi, 139p.

12. Laulanié H. (1993) Le système de riziculture intensive et la Côte-Est de Madagascar (The system of intensive rice and the East Coast of Madagascar). Lakroa, Fianarantsoa, 96p.

13. Mati B. and Nyamai, M. (2009) Promoting the system of rice intensification in Kenya. Growing more with less water -- An information brochure for training on SRI in Mwea \{Irrigation Scheme], 49p.

14. Mati B. et al. (2011) Introduction of the System of Rice Intensification in Kenya: Experiences from Mwea Irrigation Scheme. Paddy Water Environ, 145-154.

15. McDonald A.J., Hobbs P.R. and Riha S.J. (2006) Does the System of Rice Intensification outperform conventional best management ? A synopsis of the empirical record. Field Crops Res. 96, 31-36.

16. Midez del Villar P. and Bauer J.M. (2013) Le riz en Afrique de l'Ouest: Dynamiques, politiques, et perspectives (Rice in West Africa: Dynamics, politics, and perspectives). Cahiers Agriculture 22: 336-44

17. Mishra A.., Kumar P. and Ketelaar J.W. (2016). Improving ricebased rainfed production systems in Southeast Asia for contributing towards food security and rural development through sustainable crop production intensification. AIMS Agriculture and Food 1: 102-123 (doi:10.3934/agrfood.2016.2.102).

18. Moser, C. M. and Barrett, C.B. (2003) The disappointing adoption dynamics of a yield-increasing, low external input technology: the case of SRI in Madagascar. Agricultural Systems 76, 1085-1100. 
19. Seck P., Touré A., Coulibaly J., Diagne A. and Wopereis M. (2013) Africa's rice economy before and after the 2008 rice crisis. In: Realizing Africa's Rice Promise, M. Wopereis et al., eds. CABI, Wallingford, UK, 138p.

20. Serpantié G. and Rakotondramanana M. (2013) L’intensification de la riziculture malagache, en pratique (Malagasy rice intensification, in practice). Cahiers Agriculture 22: 401-10.

21. Sinha K. and Talati J. (2007) Productivity impacts of the system of rice intensification: A case study in West Bengal, India. Agricultural Water Management 87, 55-60.

22. Uphoff N. (2004) Higher yields with fewer external inputs? The system of rice intensification and potential contributions to agricultural sustainability. International Journal of Agricultural Sustainability, 1(1), 1-12.

23. Uphoff N. (2005) Features of the system of rice intensification (SRI) apart from yield. Report to International SRI Network. https://www.scribd.com/document/53067508/FEATURES-OF-THESYSTEM-OF-RICE-INTENSIFICATION

24. Uphoff N. (2007) Reducing the vulnerability of rural households through agroecological methods: Considering the System of Rice Intensification, Mondes en développement, 35: 85-100.

25. Uphoff N., Anas I., Rupela O..P., Thiyagarajan T.M. (2009) Learning about positive plant-microbial interactions from the System of Rice Intensification, Aspects of Applied Biology, 98: 29-53.

26. VECO Afrique de l’Ouest (2012) En route vers la durabilité (On the road to sustainability).

27. Verlinden E. and Soule B. (2003) Etude de la filière riz au Bénin (Study of the rice sector in Benin). Diagnostic-Plan d'Action, Cotonou: Projet d'appui dèveloppement socio-economique (PADSE), 102p. 